\title{
KEWENANGAN HAKIM TERHADAP ADANYA KETENTUAN PIDANA MINIMAL TERKAIT TINDAK PIDANA NARKOTIKA YANG DILAKUKAN \\ OLEH ANGGOTA TNI (ANALISIS PUTUSAN NOMOR 108-K/PM.II- 09/AD/IV/2015)
}

\author{
Rizky Meidiawan \\ (Mahasiswa Program S1 Fakultas Hukum Universitas Tarumanagara) \\ (E-mail: Rmeidiawan@gmail.com)
}

\section{Sugandi Ishak S.H., M.H.}

(Corresponding Author)

(Dosen Fakultas Hukum Universitas Tarumanagara. Meraih Sarjana Hukum pada Fakultas Hukum

Universitas Tarumanagara (1983), Magister Hukum pada Fakultas Hukum Universitas Indonesia

\begin{abstract}
One of the duties of the judge was to settle the case to sentence the perpetrators of the crime by saying that the defendant was acquitted or convicted based on at least 2 evidence and the judge based on the evidence was convinced that the error violated the article charged. The judge has the freedom to impose a sentence against the defendant who is not only fundamental to the provisions of the Law but also the judge can explore the values of law and justice in society. In the current practice, many judges have ruled below the minimum criminal provisions contained in an article as in the case of narcotics in this study. This cannot be blamed because the judge has the authority and freedom to make a decision, but this will certainly make legal certainty impossible. Legal problems in this research are how the authority of judges against the existence of a minimum punishment provision in narcotics crime and what constitutes the objective is stipulated by minimum punishment provisions. The research method taken is a normative juridical method, research data obtained through literature study and retrieval of decision files as a supplement. the results of the study show that judges may just make a decision under the minimum criminal provisions because the judge not only has to pay attention to legal certainty but also the purpose of other laws is to provide justice.
\end{abstract}

Keywords: The Authority of the Judge, Minimum punishment provision, narcotics crime 


\section{PENDAHULUAN}

\section{A. Latar Belakang}

Tentara Nasional Indonesia (TNI) merupakan angkatan perang Negara Republik Indonesia. Prajurit TNI adalah warga Negara Indonesia yang dilatih secara khusus, dipersiapkan dan dipesenjatai untuk tugas-tugas pertahanan negara. Sebagai figur masyarakat, Prajurit TNI dituntut untuk harus berhati-hati dalam bertindak agar tidak melakukan perbuatan yang dapat melanggar norma hukum yang berlaku. Namun, pada faktanya saat ini terdapat anggota TNI yang berperilaku menyimpang sehingga melanggar peraturan disiplin, bahkan hingga melanggar ketentuan pidana. Perbuatan yang melanggar hukum tersebut membawa konsekuensi bagi anggota TNI untuk mempertanggungjawabkan perbuatannya dalam sidang pengadilan sesuai dengan ketentuan hukum pidana yang berlaku sesuai dengan apa yang telah dirumuskan di dalam Pasaal 27 ayat (1) Undang-Undang Dasar Negara Republik Indonesia tahun 1945 yang mengatakan "seluruh warga negara kedudukannya sama mata hukum dan pemerintahan, tidak ada terkecualinya". ${ }^{1)}$

Pada saat ini, penyalahgunaan narkotika sudah menjadi masalah yang serius di Indonesia. Penyalahgunaan narkotika tidak hanya berkembang di kotakota besar saja, tetapi jaringan penyebarannya sudah merambah ke kota-kota kecil atau ke daerah-daerah, yang biasa dikenal dengan nama sistem sel dan lantas pemakaian dan peredaran narkotika dari waktu ke waktu semakin banyak $^{2)}$.

Pemakaian dan pengedar narkotika di tanah air memang telah dijerat dengan pasal-pasal hukum, namun tidak lantas membuat Negara ini terbebas dari penyalahgunaan narkotika. Hal ini memberi arti bahwa tujuan dari hukum pidana

\footnotetext{
${ }^{1)}$ Indonesia, Undang-Undang Dasar Republik Indonesia Tahun 1945 Pasal 27 ayat (1).

${ }^{2)}$ Zahroni, Pencegahan Penyalahgunaan NAPZA (Jakarta: Grafindo Awanawan, 1980), hal.
} 56. 
tersebut tidak terlaksana atau tidak terwujud. Pada Undang-Undang Narkotika diatur mengenai pidana minimal khusus. Pidana minimal khusus merupakan suatu pola perumusan sanksi, dimana adanya pengaturan mengenai pidana minimal yang dapat dijatuhkan oleh hakim terhadap suatu delik tertentu. Adanya sistem pidana minimum khusus ini diharapkan terhadap para pelaku tindak pidana penyalahgunaan narkotika dapat dikenai hukuman yang berat, hal ini dikarenakan setiap tahunnya jumlah pelaku tindak pidana narkotika semakin bertambah dan sudah menjadi masalah yang sangat serius di Negara Indonesia ini, dimana salah satu penyebabnya tidak terlepas dari ringannya putusan yang dijatuhkan oleh hakim. Padahal sudah sangat jelas bahwa narkotika memberikan dampak yang sangat buruk bagi penggunanya, bahkan tindak pidana narkotika sangat membahayakan kepentingan bangsa dan negara. ${ }^{3)}$

Saat ini masalah penyalahgunaan narkotika tidak saja terjadi pada masyarakat umum, namun sudah merambah juga hingga lingkungan prajurit TNI. Seperti yang terjadi di Cisarua kabupaten Bogor, dimana adanya oknum TNI AD yang bernama Muhibuddin dengan pangkat Pelda melakukan tindak pidana penyalahgunaan narkotika. Hasil pemeriksaan tes urine yang dilakukan di Urdokkes Polres Kabupaten Bogor menyatakan bahwa terdakwa terbukti positif Amphetamine dan Metamfetamine. Tidak hanya sekedar mengkonsumsi narkotika, terdakwa juga diketahui menjual narkotika jenis sabu-sabu. Berdasarkan Berita Acara Pemeriksaan Laboratorium Kriminalistik Nomor Lab. 3687/NNF/2014 barang bukti yang ditemukan keseluruhannya jika dijumlah beratnya mencapai 95,4614 gram

Perbuatan tersebut telah memenuhi unsur-unsur tindak pidana sebagaimana dirumuskan dan diancam dengan pidana yang tercantum dalam Pasal 112 Ayat (2) Undang-Unddang Nomor 35 Tahun 2009 tentang Narkotika

\footnotetext{
3) Moh. Taufik Makarao, et al., Tindak Pidana Narkotika, (Jakarta: Ghalia Indonesia, 2005), hal. 14.
} 
dengan ancaman pidana penjara seumur hidup atau pidana paling singkat 5 tahun dan paling lama 20 tahun dan pidana denda paling sedikit +/- Rp. 1.067.000.000 dan paling banyak +/- Rp. 10.670.000.000.

Namun, pada akhirnya hakim hanya menjatuhi terdakwa Muhibuddin dengan hukuman pidana pokok penjara selama 1 (satu) tahun, dan terhadap terdakwa juga dijatuhi pidana denda sebesar satu milyar tujuh puluh juta rupiah dengan ketentuan bila denda tersebut tidak dibayar maka diganti dengan pidana penjara selama 2 bulan, serta pidana tambahan berupa pemecatan dari dinas militer.

Jika dilihat dari putusan hakim pada kasus ini yang tidak sesuai ialah terkait dengan pidana penjaranya, dimana hakim hanya menjatuhkan pidana penjara kepada terdakwa selama 1 (satu) tahun, yang mana hal tersebut jauh di bawah ketentuan pidana minimal yang diatur di dalam Pasal 112 ayat (2) Undang-Undang Narkotika. Hakim memanglah memiliki kebebasan dalam menjatuhkan putusan, namun yang menjadi persoalan adalah sejauh manakah kebebasan yang dimiliki oleh hakim dalam menjatuhkan putusan terutama terkait dengan terdapatnya Undang-Undang yang mencantumkan ketentuan pidana minimal. Berdasarkan hal tersebut maka diangkatlah judul jurnal yaitu “Kewenangan Hakim Terhadap Adanya Ketentuan Pidana Minimal Terkait Tindak Pidana Narkotika yang Dilakukan oleh Anggota TNI (Analisis Putusan Nomor 108-K/PM.II-09/AD/IV/2015)".

\section{B. Perumusan Masalah}

1. Bagaimana kewenangan hakim terhadap adanya ketentuan pidana minimal terkait tindak pidana narkotika yang dilakukan oleh anggota TNI?

2. Apa yang menjadi tujuan ditetapkannya pidana minimal dalam tindak pidana narkotika?

\section{Metode Penelitian}




\section{Tipe Penelitian}

Tipe penelitian hukum yang digunakan adalah penelitian hukum yuridis normatif yaitu penelitian yang meletakkan hukum sebagai sebuah bangunan sistem norma. Sistem norma yang dimaksud adalah mengenai asas-asas, norma, kaidah dari peraturan perundang-undangan, putusan pengadilan, perjanjian serta doktrin (ajaran). ${ }^{4)}$ Data penelitian diperoleh melalui studi kepustakaan dan pengambilan berkas putusan Pengadilan Militer sebagai pelengkap.

\section{Spesifikasi Penulisan}

Spesifikasi penelitian yang digunakan adalah spesifikasi penelitian deskriptif analitis, yaitu menggambarkan peraturan perundang-undangan yang berlaku dikaitkan dengan teori-teori hukum dan praktik pelaksanaan hukum positif terkait permasalahan yang dibahas dalam penelitian lalu dilakukan analisis secara cermat untuk menjawab permasalahan dalam penelitian ini

\section{Jenis dan Sumber Data}

Jenis data yang digunakan adalah data sekunder, yaitu data yang sumbernya diperoleh dari bahan pustaka mencakup dokumen-dokumen resmi, buku-buku, hasil-hasil penelitian. ${ }^{5)}$ Metode kepustakaan dilakukan dengan cara mengunjungi berbagai perpustakaan seperti perpustakaan fakultas hukum Universitas Tarumanagara, Perpustakaan Nasional, dan Pengadilan militer, untuk membaca lalu menelaah serta mempelajari literatur dan sumber data lain yang berkaitan dengan materi yang dibahas dalam proposal ini baik yang berhubungan secara langsung maupun yang berhubungan secara tidak langsung.

\footnotetext{
${ }^{4)}$ Mukti Fajar ND dan Yulianto Achmad, Dualisme Penelitian Hukum Normatif dan Empiris, (Yogyakarta: Pustaka Pelajar, 2015), hal. 34.

${ }^{5)}$ Soerjono dan Sri, Op Cit., hal. 51.
} 
Bahan hukum terdiri dari bahan hukum primer, bahan hukum sekunder, dan bahan hukum tersier, adapun bahannya sebagai berikut:

a. Bahan hukum primer yaitu dengan menggunakan peraturanperaturan perundang-undangan dalam hal ini adalah UndangUndang Dasar Republik Indonesia Tahun 1945, Undang-Undang Republik Indonesia Nomor 1 Tahun 1946 tentang Kitab UndangUndang Hukum Pidana, Undang-Undang Nomor 34 tahun 2004 tentang Tentara nasional Indonesia, Undang-Undang Nomor 35 Tahun 2009 tentang Narkotika, Undang-Undang Nomor 48 Tahun 2009 tentang Kekuasaan Kehakiman dan Putusan Pengadilan Militer Nomor 108-K/PM.II-09/AD/IV/2015.

b. Bahan hukum sekunder dalam hal ini yakni berupa buku-buku dan tulisan-tulisan hukum yang terkait dengan topik pembahasan yaitu tindak pidana narkotika, kewenangan hakim dan pidana minimum khusus.

c. Bahan hukum tersier yaitu bahan hukum pustaka yang mendukung bahan hukum primer dan bahan hukum sekunder. Bahan hukum tersier yang digunakan antara lain seperti kamus dan ensiklopedia.

\section{Teknik Pengumpulan Data}

Pengumpulan data dilakukan melalui studi dokumen terhadap data sekunder. Untuk data sekunder pada penelitian hukum dapat dibatasi penggunaan studi dokumen atau bahan pustaka saja. ${ }^{6)}$ Metode kepustakaan dilakukan dengan cara mengunjungi berbagai perpustakaan seperti perpustakaan fakultas hukum Universitas Tarumanagara, Perpustakaan Nasional, dan Pengadilan militer, untuk membaca lalu menelaah serta mempelajari literatur dan sumber data lain yang berkaitan dengan materi yang 
dibahas dalam karya tulis ini baik yang berhubungan secara langsung maupun yang berhubungan secara tidak langsung.

\section{Teknik Pengolahan Data}

Setelah semua data dan bahan dikumpulkan, dilakukan pengolahan data secara kualitatif, yaitu pengolahan data yang mengacu pada norma hukum yang terdapat dalam peraturan perundang-undangan dan putusan pengadilan serta norma-norma yang hidup dan berkembang dalam masyarakat. ${ }^{7)}$

Dalam penelitian hukum normatif, pengolahan dan bahan hukum berwujud kegiatan untuk mengadakan sistematisasi terhadap data dan bahan hukum tertulis dengan cara melakukan seleksi data sekunder dilanjutkan dengan kualifikasi dan menyusun data hasil penelitian tersebut secara sistematis dan logis. ${ }^{8)}$

\section{Teknik Analisis Data}

Teknik analisis data menggunakan teknik deduktif yaitu, teknik yang berpangkal dari premis mayor (pernyataan yang bersifat umum), lalu kemudian diajukan premis minor (bersifat khusus), dari kedua premis tersebutlah kemudian ditarik kesimpulan.

\section{PEMBAHASAN}

\section{A. Kasus Posisi}

Berawal pada tanggal 19 September 2014 pukul 21.00 WIB anggota Satnarkoba Polres Bogor melakukan penangkapan terhadap saudara Budiman, Genu, dan Usep di jl. Amper, Desa tugu selatan Kecamatan cisarua Kabupaten Bogor. Hasil penggeledahan terhadap ketiganya ditemukan barang bukti berupa 1 (satu) bungkus plastik kecil warna putih bening berisikan sabu-sabu di dalam tas selempang warna hitam merek Gress milik Budiman, kemudian di dalam saku celana bagian depan

\footnotetext{
7)Zainuddin Ali, Metode Penelitian Hukum, (Jakarta: Sinar Grafika, 2010), hal. 106.

${ }^{8)}$ Soerjono dan Sri, Op Cit., hal. 252.
} 
Genu ditemukan 1 (satu) bungkus plastik kecil warna putih berisi sabu-sabu dan di saku celana jeans bagian depan Usep ditemukan 1 (satu) kantong plastik bening warna putih berisikan sabu-sabu. Ketiganya pun kemudian dibawa ke Polres Bogor. Setelah dilakukan pengembangan melalui Introgasi Budiman, Genu, dan Usep mengakui bahwa barang tersebut didapatkan dari seseorang yang berinisial Abah Udin yang beralamat di Kampung Sampora Desa Sampora Kecamatan Cibinong Kabupaten Bogor, yang merupakan seorang anggota TNI AD berpangkat Pelda dari kesatuan Babinminvetcaddam III/siliwangi. Setelah memperoleh informasi tersebut, masih pada hari yang sama pada pukul 23.10 WIB anggota Satnarkoba Polres Bogor bersama dengan para tersangka menuju ke rumah seseorang yang berinisial abah udin yang beralamat di Kp. Sampora Desa Sampora Kec. Cibinong Kab. Bogor.

Kemudian, sesampainya di sana anggota Satnarkoba Polres Bogor mengetuk pintu rumah yang kemudian dibuka oleh seorang anak laki-laki. Anggota pun langsung masuk ke dalam rumah dan menemui abah Udin di kamar mandi seperti hendak membuang barang-barang berupa narkoba, yang kemudian ditemukan 1 (satu) kantong plastik berukuran besar warna putih bening yang berisi serbuk putih seperti kristal di dalam lubang closet WC dan di lantai kamar mandi ditemukan 1 (satu) kantong plastik berukuran besar warna putih bening berisi serbuk putih seperti kristal, 4 (empat) kantong plastik berukuran sedang warna putih bening berisi serbuk warna putih seperti kristal dan 3 (tiga) kantong plastik berukuran kecil warna putih bening berisi serbuk warna putih seperti Kristal putih yang mengandung Metamfetamine dan terdaftar dalam narkotika golongan I Nomor urut 61 Lampiran Undang-undang Republik Indonesia No. 35 tahun 2009 tentang narkotika.

Pada penggeledahan anggota Satnarkoba lainnya di lantai atas ditemukan juga 1 (satu) unit timbangan elektrik di atas meja ruang tamu sedangkan di kamar terdakwa di lantai bawah Brigadir Alfi Fauzi menemukan sebuah tas selempang kecil warna hitam bertuliskan Santer Brighter future yang berisi sejumlah uang. Setelah diintrogasi, terdakwa mengaku barang-barang tersebut miliknya yang diperoleh dari 
temannya yang bernama saudara Sipayung. Uang yang berada di tas warna hitam bertuliskan Santer Brighter future setelah dihitung berjumlah Rp. 40.000.000,- (empat puluh juta rupiah) yang terdiri dari uang pecahan Rp.100.000,-(seratus ribu) sebanyak 395 (tiga ratus sembilan puluh lima) lembar dan Rp.50.000,- (lima puluh ribu ) sebanyak 10 (sepuluh lembar), uang tersebut merupakan hasil penjualan narkotika jenis sabu-sabu dan penjualan ikan. Terdakwa akhirnya di bawa ke Polres Kabupaten Bogor dan di Polres Kabupaten Bogor, Tim dari Urdokkes Polres Kabupaten Bogor pun melakukan tes urine terhadap terdakwa muhibuddin dan hasil pemeriksaan tes urine terhadap terdakwa, dinyatakan bahwa terdakwa terbukti positif Amphetamine dan Metamfetamine, lalu kemudian karena terdakwa adalah anggota TNI AD yang masih berdinas aktif maka selanjutnya terdakwa diserahkan ke Pomdam III Siliwangi untuk diproses lebih lanjut di Denpom III/1 Bogor.

Berdasarkan Berita Acara Pemeriksaan Laboratorium Kriminalistik Nomor Lab. 3687/NNF/2014 barang bukti sabu yang ditemukan keseluruhannya jika dijumlah beratnya mencapai 95,4614 gram

\section{B. Dakwaan Oditur Militer}

Berdasarkan surat Dakwaan Oditur Militer Nomor : Sdak/43/K/AD/II-09/ III/2015 bahwa tindak pidana yang dilakukan oleh Terdakwa sebagaimana dakwaan Oditur Militer disusun dalam bentuk alternatif yaitu:

a) Alternatif pertama pasal 127 ayat (1) huruf a UURI Nomor 35 tahun 2009 jo pasal 55 ayat (1) KUHP dengan ancaman pidana penjara paling lama 4 (empat) tahun.

b) Alternatif kedua pasal 112 ayat (2) UURI Nomor 35 tahun 2009. Terdakwa pada pokoknya didakwa sebagai berikut : Bahwa Terdakwa telah melakukan tindak pidana : "Setiap orang secara tanpa hak atau melawan hukum memiliki, menyimpan, menguasai atau menyediakan narkotika golongan I bukan tanaman yang beratnya melebihi 5 (lima) gram " dengan ancaman pidana penjara seumur hidup atau pidana penjara paling singkat 5 (lima) 
tahun dan paling lama 20 (dua puluh) tahun dan pidana denda paling sedikit +/- Rp. 1.067.000.000 dan paling banyak +/- Rp. 10.670.000.000

\section{Putusan Hakim}

A. Menyatakan Terdakwa Muhibuddin terbukti secara sah dan meyakinkan bersalah melakukan tindak pidana : "Setiap orang yang tanpa hak dan melawan hukum memiliki dan menguasai Narkotika Golongan I bukan tanaman yang beratnya melebihi 5 (lima) gram" (Pasal 112 ayat (2) UndangUnndang Nomor 35 Tahun 2009 tentang Narkotika).

B. Memidana Terdakwa oleh karena itu dengan :

- Pidana Pokok : Penjara Selama 1(satu) tahun Menetapkan selama waktu Terdakwa berada dalam tahanan sementara perlu dikurangkan seluruhnya dari pidana yang dijatuhkan.

- Pidana denda : Sebesar Rp.1.070.000.000,- (satu milyar tujuh puluh juta rupiah). Dengan ketentuan apabila denda tersebut tidak dibayar maka diganti dengan pidana penjara selama 2 (dua) bulan.

- Pidana tambahan : Dipecat dari dinas Militer.

\section{E. Hasil Wawancara}

\section{Budi Prasetyo S.H., M.H. selaku Dosen Universitas Tarumanagara9)}

Berdasarkan wawancara penulis dengan Bapak Budi Prasetyo, beliau berpendapat bahwa apa yang telah dilakukan atau diputuskan oleh hakim sudahlah benar, apa yang dilakukan oleh hakim tidaklah menyalahi hukum dikarenakan penjatuhan pidana merupakan hak pererogatif hakim, hakim memiliki kewenangan dan kebebasan dalam menjatuhkan putusan

\footnotetext{
${ }^{9}$ 'Peneliti, Wawancara dengan Bapak Budi Prasetyo, selaku Dosen Fakultas Hukum
} Universitas Tarumanagara, (Jakarta, 18 Oktober 2018). 
beradasarkan keyakinan hakim didalam membuktikan suatu perkara, sehingga sekalipun hakim menjatuhkan putusan di bawah dari pidana minimal yang tercantum pada suatu pasal di dalam suatu Undang-Undang hal itu tetap sah-sah saja, karena pada dasarnya dalam menjatuhkan putusan hakim mempertimbangkan berbagai macam faktor hingga jatuhnya suatu putusan.

Kemudian, Budi Prasetyo juga berpendapat bahwa hal yang menyebabkan Indonesia menjadi sarang bagi peredaran dan penyalahgunaan narkotika ialah berkaitan dengan kesejahteraan masyarakat. Kesejahteraan ini berkaitan juga dengan budaya bangsa Indonesia, dimana pola tingkat kerja masyarakat indonesia masihlah sangat kurang sehingga masyarakat Indonesia cenderung untuk lebih mencari jalan pintas dengan cara mencari uang dengan cara yang instan, namun hasil yang terbilang besar sehingga dengan pola budaya yang seperti itu masyarakat Indonesia cenderung menjadi mudah untuk terbawa atau terpengaruh dengan iming-iming jika menjual narkotika akan memperoleh keuntungan yang besar yang hasilnya digunakan untuk mencukupi kehidupan (mensejahterakan keluarganya). Kemudian hal lain yang juga berkaitan dengan Indonesia yang menjadi sarang bagi penyalahgunaan dan peredaran narkotika ialah tingkat kesadaran tentang akan bahaya narkotika di Indonesia masih sangat rendah dan hukuman bagi para pelanggaranya masih belum tegas sehingga tidak memberikan efek jera bagi para pelaku tindak pidana narkotika.

\section{Mayor Chk Salmon Balubun, S.H., M.H. selaku Konsitut Otmil II-07} Jakarta $^{10)}$

Berdasarkan wawancara penulis dengan Mayor Salmon Balubun, beliau berpendapat bahwa Perkara yang sudah ada batasannya baik pidana

\footnotetext{
${ }^{10)}$ Peneliti, Wawancara dengan Bapak Salomon Balubun, selaku Konstitut Otmil II-07 Jakarta, (Jakarta, 2 November 2018).
} 
minimal maupun pidana maksimal menurut Salmon Balbun S.H., M.H. hakim seharusnya tidak boleh menjatuhkan putusan melanggar dari ketentuan pidana minimal maupun pidana maksimal yang ada, walaupun hakim punya kewenangan dalam kebebasan menjatuhkan pidana. Beliau berpendapat bahwa hakim seharusnya dapat menjatuhkan putusan sesuai dengan ketentuan undang-undang (tidak melanggar ketentuan pidana minimal) terkait kasus narkotika, karena bagi beliau tindak pidana narkotika di lingkungan TNI tidak ada ruang atau tidak ada maaf bagi para pelakunya dan harus ditindak tegas.

Terkait Indonesia yang menjadi sarang dari peredaran dan penyalahgunaan narkotika Salmon Balubun berpendapat bahwa hal itu terkait dengan masalah pemidanaan, yang mana pemidanaan ini masih terlalu ringan sehingga tidak memberikan efek jera bagi para pelakunya, Yang kedua ialah pembinaan bagi para narapidana narkotika belumlah memberikan efek jera karena seperti diketahui bahwa saat ini peredaran dan penyalahgunaan narkotika sudah sampai masuk ke dalam lembaga pemasyarakatan, yang mana itu artinya dari sisi aparat juga harus ada perbaikan, sehingga tidak hanya penegakannya tetapi penindakannya juga harus tegas. Perlunya juga peran dari masyarakat untuk mau proaktif dalam memerangi narkotika, sehingga haruslah diubah pemikiran mengenai lebih baik diam atau pura-pura tidak tahu disaat kita melihat penyalahgunaan narkotika terjadi disekitar kita demi keamanan diri kita, karena pada faktanya keterlibatan masyarakat merupakan hal yang sangat penting dalam usaha untuk memerangi narkotika.

\section{Satiman S.H., M.H. selaku Panitera Pengadilan Militer II-08 Jakarta ${ }^{11)}$}

${ }^{11)}$ Peneliti, Wawancara dengan Bapak Satiman, selaku Panitera Pengadilan Militer II-08 Jakarta, (Jakarta, 8 November 2018). 
Berdasarkan wawancara penulis dengan Lettu Satiman S.H., M.H. selaku Panitera Pengadilan Militer II-08 Jakarta yang mewakili Hakim Pengadilan Militer II-08 Jakarta, Satiman S.H., M.H. berpendapat bahwa berdasarkan ST Panglima, anggota TNI yang terbukti melakukan tindak pidana narkotika dianggap sudah tidak layak untuk dipertahankan dalam keluarga besar TNI, mereka sudah dianggap tidak mampu untuk melaksanakan tugas sebagai seorang prajurit TNI, sehingga sudah diwajibkan untuk dipecat jika terbukti melakukan tindak pidana narkotika. Narkotika pun di Indonesia ini sudahlah dapat dikatakan darurat, dikarenakan jumlah penyalahguna narkotika yang setiap tahunnya bertambah sehingga haruslah ada tindakan tegas untuk memberantas narkotika. Penjatuhan pidana yang berat memanglah merupakan salah satu cara dalam upaya memberantas narkotika namun pada dasarnya Hakim dalam memutus suatu perkara didasarkan atas hati nurani dan berbagai pertimbangan. Semestinya hakim memang haruslah memberikan hukuman yang berat kepada pelaku tindak pidana narkotika, apalagi pelaku adalah seorang anggota TNI. Namun kembali lagi, pada parkteknya hakim juga harus mempertimbangkan banyak hal dalam memutus suatu perkara, dan hakim bukanlah corong suatu undang-undang. Pada kenyataannya pun pembinaan dalam Lembaga Permasyarakatan (Lapas) belumlah cukup baik di Indonesia ini, sehingga yang banyak terjadi ialah bukannya memberikan efek jera bagi narapidana, namun malah membuat tambah parah. Sehingga Satiman S.H., M.H. setuju jika pelaku tindak pidana narkotika seharusnya dijatuhkan hukuman yang berat (tidak melanggar ketentuan pidana minimal) sebagai salah satu upaya untuk memberantas narkotika, namun haruslah diperbaiki juga pembinaannya di dalam Lemabaga Permasyarakatan (Lapas) agar tujuan dari pembinaan tersebut dapat tercapai. Namun menurut beliau apa yang dilakukan oleh hakim tersebut tidaklah melanggar hukum karena 
kembali pada penjelasan diatas bahwa hakim dalam menjatuhkan putusan pastilah didasarkan atas suatu pertimbangan dan hasil musyawarah dengan hakim anggota.

Terkait Indonesia yang menjadi sarang dari peredaran dan penyalahgunaan narkotika Satiman S.H., M.H. berpendapat bahwa hal itu terkait masalah kesejehateraan masyarakat Indonesia yang masih sangat rendah sehingga banyak orang mengambil jalan pintas untuk dapat hidup sejahtera yaitu salah satunya dengan melakukan jual beli narkotika dan penyebab kedua ialah kurangnya pengetahuan mengenai bahaya dari narkotika dan anggapan yang salah tentang narkotika dan faktor lainnya ialah terkait masalah pembinaan terhadap pelaku tindak pidana narkotika yang masih belum cukup baik.

4. Agus Pambudi S.H., M.H. selaku Hakim Pengadilan Negeri Jakarta Barat $^{12)}$

Berdasarkan wawancara penulis, Agus Pambudi S.H., M.H. berpendapat bahwa hakim memiliki kewenangan atau kebebasan dalam menjatuhkan putusan namun kebebasan yang dimiliki oleh hakim tetaplah saja harus berpatokan dengan undang-undang karena hakim merupakan pelaksana Undang-Undang. Terkait penjatuhan putusan dibawah pidana minimal yang tertulis didalam suatu pasal, hakim memang boleh saja menjatuhkan putusan dibawah pidana minimal tetapi hal tersebut haruslah berdasakan pertimbangan yang matang sehingga haruslah ada dasarnya hakim dalam menjatuhkan putusan tersebut. Namun terkait kasus penulis, Agus Pambudi S.H., M.H. berpendapat bahwa seharusnya hakim tidak menjatuhkan pidana di bawah ketentuan pidana minimal dalam pasal 112

${ }^{12)}$ Peneliti, Wawancara dengan Bapak Agus Pambudi, selaku Hakim Pengadilan Negeri Jakarta Barat, (Jakarta, 21 Desember 2018). 
ayat (2) Undang-Undang Narkotika, dikarenakan terdakwa telah terbukti melakukan penjualan narkotika serta mengkonsumsi narkotika dan dalam pemeriksaan pun ditemukan sabu seberat 95,46 gram sehingga dengan begitu sudah sepantasnya hakim menjatuhkan pidana sesuai dengan yang tertulis di dalam Pasal 112 ayat (2) karena terdakwa terbukti menguasai, atau menyediakan narkotika golongan I yang beratnya melebihi 5 gram.

Kemudian masalah terkait Indonesia yang menjadi sarang dari peredaran dan penyalahgunaan narkotika Agus Pambudi S.H., M.H. berpendapat bahwa permasalahan tersebut sudahlah sangat kompleks, mulai dari aparatnya, pemidanaannya, dan lainnya. Namun, Menurut Agus Pambudi S.H., M.H. yang menjadi faktor yang paling berpengaruh terkait masalah tersebut dapat dilihat dari banyak tidaknya atau mudah tidaknya narkotika tersebut masuk ke wilayah Indonesia, karena sebagian besar narkotika bukanlah dibuat di Indonesia. sehingga selama narkotika tersebut masih mudah untuk masuk ke wilayah Indonesia maka sangatlah sulit untuk mengatasi hal tersebut, Hal ini pun terkait Indonesia yang merupakan Negara kepulauan sehingga terlalu banyak akses untuk dapat masuk ke wilayah Indonesia, hal inilah yang membuat sulitnya untuk dapat menyaring barangbarang yang masuk sehingga seringkali narkotika tersebut masuk melalui jalur- jalur tikus atau pelabuhan-pelabuhan kecil. Karena terlalu banyaknya pintu masuk ke wilayah Indonesia inilah yang membuat sulit untuk dapat konsentrasi dalam mengendalikan barang-barang yang masuk atau untuk mempersulit masuknya barang-barang terlarang seperti narkotika.

\section{F. Analisis}

Di dalam perkembangan pembuatan undang-undang saat ini telah terdapat beberapa Perundang-undangan yang di dalamnya memuat sistem pidana minimal khusus dan pidana maksimum khusus. Pada prinsipnya pidana minimum khusus terdapat pada Undang-Undang yang mengatur tindak pidana yang dipandang sangat 
merugikan atau meresahkan masyarakat. Salah satu Undang-Undang yang di dalamnya memuat ketentuan pidana minimum khusus ialah Undang-Undang Nomor 35 Tahun 2009 tentang Narkotika.

Saat ini penyalahgunaan narkotika telah menjadi masalah yang sangat serius di berbagai negara, tak terkecuali Indonesia. Salah satu yang menjadi penyebabnya ialah tidak terlepas dari ringannya hukuman dan putusan yang dijatuhkan oleh hakim sehingga penjatuhan pidana tersebut tidak memberikan efek jera bagi para pelakunya. Padahal sudah sangat jelas narkotika memberikan dampak yang sangat buruk bagi penggunanya, bahkan tindak pidana narkotika sangat membahayakan kepentingan bangsa dan Negara. ${ }^{13)}$

Terdapatnya ketentuan pidana minimum khusus di dalam Undang-Undang narkotika diharapkan dapat memberikan batasan terhadap kebebasan yang dimiliki hakim didalam menjatuhkan putusan dan dengan adanya sistem pidana minimum khusus juga diharapkan terhadap para pelaku tindak pidana penyalahgunaan narkotika dapat dikenai hukuman yang berat sehingga memberikan efek jera bagi para pelakunya dan untuk mencegah niat orang yang hendak melakukan tindak pidana tersebut. Apalagi saat ini jumlah pelaku tindak pidana narkotika setiap tahunnya semakin bertambah dan sudah menjadi masalah yang sangat serius di Indonesia.

Salah satu kasus penyalahgunaan narkotika yang menarik perhatian penulis ialah kasus tindak pidana narkotika yang melibatkan anggota TNI bernama Muhibuddin di Cisarua kabupaten Bogor. Terdakwa terbukti menjual dan mengkonsumsi narkotika jenis sabu, yang mana saat pemeriksaan diperoleh barang bukti berupa sabu yang beratnya berjumlah 95,4614 gram. Terdakwa Muhibuddin didakwakan dengan Pasal 112 Ayat (2) Undang-Undang Nomor 35 tahun 2009 tentang Narkotika dengan ancaman pidana penjara seumur hidup atau pidana paling hal. 14 .

${ }^{13)}$ Moh. Taufik Makarao, et al., Tindak Pidana Narkotika, (Jakarta: Ghalia Indonesia, 2005), 
singkat 5 tahun dan paling lama 20 tahun dan pidana denda paling sedikit $+/-$ Rp. 1.067.000.000 dan paling banyak +/- Rp. 10.670.000.000.

Pada kasus tersebut pada akhirnya Hakim menjatuhi pidana penjara kepada terdakwa muhibuddin selama 1 tahun dan denda sebesar satu milyar tujuh puluh juta rupiah dengan ketentuan bila denda tersebut tidak dibayar maka diganti dengan pidana penjara selama 2 bulan, serta pidana tambahan berupa pemecatan dari dinas militer. Pidana penjara selama 1 tahun yang diputus oleh hakim tidaklah sejalan dengan ketentuan Pasal 112 ayat (2) Undang-Undang Nomor 35 Tahun 2009 tentang Narkotika, dimana pada pasal ini telah diatur mengenai pidana minimal yang dapat dijatuhkan oleh hakim yaitu selama 5 tahun. Penjatuhan pidana di bawah dari ketentuan pidana minimal ini tentunya menimbulkan pro dan kontra dari berbagai kalangan masyarakat.

Berdasarkan pemahaman penulis terhadap kasus dan jawaban para narasumber dari hasil wawancara maka penulis berpendapat bahwa pada dasarnya hakim memang memiliki kewenangan dan kebebasan dalam menjatuhkan putusan. Sehingga apabila hakim menjatuhi pidana dibawah dari ketentuan pidana minimal hal tersebut tidaklah menyalahi hukum. Hakim memang boleh saja menjatuhkan pidana kepada terdakwa di bawah ketentuan pidana minimal, namun hal tersebut haruslah memiliki dasar, yaitu berdasarkan pertimbangan yang matang seperti contohnya dilihat dari hal-hal yang meringankan terdakwa, atau fakta-fakta yang diperoleh selama jalannya persidangan. Hal ini dilakukan karena hakim bukanlah sebuah corong suatu Undang-Undang. Sebab di lain sisi hakim juga harus menegakkan nilainilai keadilan karena itu pun juga merupakan salah satu tujuan diadakannya pemeriksaan di persidangan, yang tidak lain untuk memperoleh fakta-fakta guna menegakkan nilai-nilai keadilan. 
Namun pada kasus Muhibuddin, Penulis kurang sependapat dengan apa yang diputus oleh hakim Pengadilan Militer, dikarenakan dengan pertimbangan penulis mengenai Indonesia yang telah darurat Narkotika dan pada kasus tersebut sudahlah sangat jelas bahwa terdakwa Muhibuddin tidaklah hanya sebagai korban Narkotika (mengkonsumsi atau sebagai pengguna), melainkan terdakwa juga terbukti melakukan penjualan narkotika jenis sabu. Kemudian pada saat penggerebekan pun polisi menemukan sabu seberat 95,46 gram dari rumah terdakwa yang sebelumnya terdakwa muhibuddin berusaha untuk membuangnya ke dalam wc toilet. Sehingga dengan begitu menurut hemat penulis sudah sepantasnya hakim menjatuhkan pidana sesuai dengan yang tertulis di dalam Pasal 112 ayat (2) karena terdakwa telah terbukti menguasai, menyediakan narkotika golongan I yang beratnya melebihi 5 gram, atau dengan kata lain hakim sudah seharusnya memperhatikan ketentuan pidana minimal pada Pasal 112 Ayat (2) tersebut yakni dengan tidak menjatuhkan pidana kepada terdakwa hanya selama 1 tahun (di bawah dari ketentuan pidana minimal dalam pasal 112 ayat (2) Undang-Undang Narkotika). Terlebih jika kita lihat bahwa saat ini narkotika sudah menjadi masalah yang sangat serius di Indonesia dan diketahui juga pada prinsipnya pidana minimum khusus ini hanya terdapat pada Undang-Undang yang mengatur tindak pidana yang dipandang sangat merugikan atau meresahkan masyarakat, salah satunya adalah Undang-Undang Nomor 35 Tahun 2009 tentang Narkotika. Sehingga, penulis berpendapat bahwa sudah seharusnya para penyalahguna narkotika khususnya bandar atau penjual narkotika diberikan hukuman yang berat, yang mana itu artinya hakim haruslah memperhatikan ketentuan pidana minimal khusus dalam Undang-Undang Narkotika. Hal ini pun tidak lain agar para pelaku tindak pidana narkotika khususnya Bandar atau penjual narkotika dapat memperoleh hukuman yang berat sehingga diharapkan dapat memberikan efek jera bagi pelaku serta mencegah niat orang lain untuk melakukan tindak pidana tersebut. 
Kemudian dengan fakta yang diperoleh bahwa terdakwa adalah seorang anggota TNI tentu hal tersebut sangatlah disayangkan, karena sejatinya seorang prajurit TNI sebagai Aparatur Negara atau figur publik haruslah memiliki perilaku yang dapat menjadi contoh bagi masyarakat. Tingkat kedisiplinan prajurit TNI yang rendah dikarenakan adanya prajurit yang melakukan tindak pidana penyalahgunaan narkotika pun akan berdampak buruk pada pelaksanaan tugas pokok TNI yaitu menjaga kedaulatan wilayah Negara Kesatuan Republik Indonesia, hal ini dikarenakan keberhasilan tugas pokok TNI dapat ditentukan oleh tinggi atau rendahnya tingkat disiplin prajurit TNI.

Pada Undang-Undang Nomor 34 Tahun 2004 tentang Tentara Nasional Indonesia (TNI) dijelaskan mengenai salah satu tugas pokok dan fungsi TNI yang masuk kedalam operasi militer selain perang (OMSP) yaitu membantu Kepolisian Negara Republik Indonesia dalam rangka tugas keamanan dan ketertiban masyarakat yang diatur dalam undang-undang. Dengan demikian apabila ditemukan anggota militer yang terlibat dalam peredaran narkotika hal tersebut jelas sangat bertentangan dengan tugas pokok dan fungsi anggota militer seperti yang tercantum dalam undangundang tersebut. Hal tersebutlah yang kemudian menurut penulis menjadi dasar bahwa seharusnya terdakwa Muhibuddin mendapatkan pidana yang lebih berat dari yang diterima, karena secara tidak langsung pun terdakwa muhibuddin telah mencoreng citra nama baik keluarga besar Tentara Nasional Indonesia (TNI).

Mengenai penyalahgunaan narkotika yang sudah menjadi masalah yang sangat serius di Indonesia memanglah disebabkan oleh berbagai macam faktor. Indonesia memang telah memilki Undang-Undang yang mengatur tentang narkotika dan Indonesia pun memiliki Badan Narkotika Nasional (BNN). Namun dengan begitu tidak ayal membuat Indonesia terbebas dari peredaran narkotika secara illegal. Undang-Undang Nomor 35 Tahun 2009 tentang Narkotika dibuat memiliki beberapa tujuan antara lain: 
1. Menjamin ketersediaan Narkotika untuk keppentingan pelayanan kesehatan dan/atau pengembangan ilmu pengetahuan dan teknologi;

2. Mencegah, melindunngi, dan menyelamatkan bangsa Indonesia dari penyalahgunaan Narkotika;

3. Memberantas peredaran gelap Narkotika dan Prekursor Narkotika; dan

4. Menjamin pengatturan upaya rehabilitasi medis dan sosial bagi Penyalah Guna dan pecandu Narkotika. ${ }^{14)}$

Namun pada faktanya saat ini sepertinya tujuan dari Undang-Undang Narkotika tersebut khususnya butir ke- 2 dan ke-3 belumlah terwujud. Pemidanaan pun telah dilakukan bagi para pelaku tindak pidana narkotika namun pemidanaan yang semestinya bertujuan untuk memberikan efek jera bagi para pelaku sepertinya belumlah juga dapat terealisasi. Para pembuat Undang-Undang dalam menyusun Undang-Undang Narkotika pun telah memasukkan ketentuan pidana minimal khusus, yang mana itu artinya tindak pidana narkotika sudah dianggap sebagai suatu tindak pidana yang meresahkan atau membahayakan masyarakat sehingga dengan adanya ketentuan pidana minimal khusus diharapkan dapat memberikan hukuman yang cukup berat bagi para pelanggarnya dengan tujuan untuk membuat para pelaku jera. Namun lagi-lagi pada prakteknya masih banyak hukuman yang dijatuhkan oleh hakim yang dinilai kurang berat atau kurang memberikan efek jera bagi para pelaku tindak pidana narkotika sehingga membuat penyalahgunaan narkotika tetap eksis di Indonesia.

Penulis sependapat dengan apa yang dikemukakan oleh bapak Agus Pambudi bahwa permasalahan ini sudah sangat kompleks, mulai dari aparatnya, pemidanaannya yang dinilai masih belum baik, pembinaan di dalam Lembaga Permasyarakatan (Lapas) yang masih buruk, masalah kesejahteraan masyarakat dan memanglah benar yang menjadi faktor yang paling berpengaruh terkait masalah tersebut sebetulnya dapat dilihat dari banyak tidaknya atau mudah tidaknya narkotika

14) Indonesia, Undang-Undang Nomor 35 Tahun 2009 tentang Narkotika Pasal 4. 
tersebut masuk ke wilayah Indonesia, karena sebagian besar narkotika bukanlah dibuat di Indonesia sehingga selama narkotika tersebut masih mudah untuk masuk ke wilayah Indonesia maka sangatlah sulit untuk mengatasi hal tersebut. Hal ini pun terkait Indonesia yang merupakan Negara kepulauan sehingga terlalu banyak akses masuk ke wilayah Indonesia, hal inilah yang membuat sulitnya untuk dapat menyaring barang-barang yang masuk sehingga seringkali narkotika tersebut masuk melalui jalur- jalur tikus atau pelabuhan-pelabuhan kecil. Karena terlalu banyaknya pintu masuk ke wilayah Indonesia inilah yang membuat sulit untuk dapat konsentrasi dalam mengendalikan barang-barang yang masuk atau untuk mempersulit masuknya barang-barang terlarang seperti narkotika.

Sehingga untuk dapat meberantas narkotika atau setidaknya meminimalisir penyalahgunaan narkotika sepertinya pemerintah harus bekerja ekstra atau membuat banyak perubahan seperti dimulai dengan memperbaiki kesejahteraan masyarakat sehingga masyarakat tidak harus melakukan tindak pidana untuk dapat memenuhi kebutuhannya lalu kemudian harus mempersempit akses masuk narkotika, mungkin dengan melakukan penjagaan yang ketat pada tiap pintu masuk Indonesia, yang itu artinya harus mempunyai personil keamanan yang banyak, lalu juga memperbaiki mental para aparat hukum dan tentunya memperbaiki pembinaan di dalam lapas agar tidak ada lagi peredaran narkotika di dalam lapas sehingga tujuan dari pemidanaan itu sendiri yaitu merehabilitasi pelaku dan memberika efek jera kepada para pelaku dapat terwujud.

\section{PENUTUP}

\section{A. Kesimpulan}

1. Hakim memiliki kewenangan dan kebebasan dalam menjatuhkan putusan. Sehingga apabila hakim menjatuhi pidana dibawah dari ketentuan pidana minimal hal tersebut tidaklah menyalahi hukum. Hakim memang boleh saja menjatuhkan pidana kepada terdakwa di bawah ketentuan pidana 
minimal, namun hal tersebut haruslah memiliki dasar, yaitu berdasarkan pertimbangan yang matang seperti contohnya dilihat dari hal-hal yang meringankan terdakwa, atau fakta-fakta yang diperoleh selama jalannya persidangan. Hal ini dilakukan karena hakim bukanlah sebuah corong suatu Undang-Undang, sebab di lain sisi hakim juga harus menegakkan nilai-nilai keadilan dan itu pun juga merupakan salah satu tujuan diadakannya pemeriksaan di persidangan, yang tidak lain untuk memperoleh fakta-fakta guna menegakkan nilai-nilai keadilan. Namun khususnya pada kasus Muhibuddin dan pertimbangan penulis terkait Indonesia yang sudah darurat Narkotika kesimpulannya adalah sudah seharusnya hakim menjatuhkan putusan sesuai dengan ketentuan pidana minimal yang diatur di dalam Pasal 112 Ayat (2) Undang-Undang Nomor 35 Tahun 2009 tentang Narkotika dikarenakan pada kasus tersebut sudahlah sangat jelas bahwa terdakwa Muhibuddin tidaklah hanya sebagai korban Narkotika (mengkonsumsi atau sebagai pengguna), melainkan terdakwa juga terbukti melakukan penjualan narkotika jenis sabu yang pada saat penggerebekan polisi menemukan sabu seberat 95,46 gram dari rumah terdakwa. Hal ini tidak lain agar para pelaku tindak pidana narkotika khususnya Bandar atau penjual narkotika dapat memperoleh hukuman yang berat sehingga diharapkan dapat memberikan efek jera bagi pelaku serta mencegah niat orang lain untuk melakukan tindak pidana tersebut.

2. Tujuan dari ketentuan pidana minimal adalah untuk memberikan batasan terhadap kebebasan yang dimiliki oleh hakim dalam menjatuhkan putusan karena pada dasarnya ketentuan pidana minimal khusus ini ada pada Undang-Undang yang mengatur tindak pidana yang dianggap membahayakan atau meresahkan masayarakat, salah satu contohnya adalah Undang-Undang Nomor 35 Tahun 2009 tentang Narkotika. 
Adanya ketentuan pidana minimal pada Undang-Undang Narkotika diharapkan hakim dapat menjatuhkan pidana yang berat terhadap pelaku sehingga tujuan dari pemidanaan yaitu memberikan efek jera terhadap pelaku atau khususnya memberantas peredaran narkotika secara ilegal dapat terwujud. Namun pada faktanya hal tersebut pun tidak dapat menjanjikan Indonesia terbebas dari peredaran narkotika secara ilegal dikarenakan oleh berbagai macam faktor, mulai dari aparatnya yang belum cukup baik, pemidanaannya yang dinilai masih belum baik, pembinaan di dalam Lembaga Permasyarakatan (Lapas) yang masih buruk serta ditambah lagi Indonesia merupakan Negara kepulauan sehingga terlalu banyak akses untuk dapat masuk ke wilayah Indonesia sehingga sulit untuk mengendalikan atau menyaring barang-barang yang masuk.

\section{B. Saran}

1. Terkait kasus Narkotika khususnya yang pelakunya telah terbukti sebagai penjual narkotika sudah seharusnya hakim memperhatikan betul ketentuan pidana minimal. Hal ini dikarenakan narkotika telah menjadi masalah yang serius di Indonesia sehingga sudah sepantasnya terhadap pelaku di jatuhi hukuman yang berat agar memberikan efek jera terhadap pelaku dan mencegah orang lain untuk melakukan tindak pidana yang sama. Hal ini tidak lain untuk mewujudkan Indonesia yang bebas dari penyalahgunaan narkotika.

2. Untuk dapat memberantas narkotika atau setidaknya meminimalisir penyalahgunaan narkotika disarankan Pemerintah harus bekerja ekstra dan membuat banyak perubahan seperti dimulai dengan memperbaiki kesejahteraan masyarakat sehingga masyarakat tidak harus melakukan tindak pidana untuk dapat memenuhi kebutuhannya lalu kemudian harus mempersempit akses masuk narkotika, mungkin dengan melakukan 
penjagaan yang ketat pada tiap pintu masuk Indonesia, yang itu artinya harus mempunyai personil keamanan yang banyak, lalu juga memperbaiki mental para aparat hukum dan tentunya memperbaiki pembinaan di dalam lapas agar tidak ada lagi peredaran narkotika di dalam lapas sehingga tujuan dari pemidanaan itu sendiri yaitu merehabilitasi pelaku dan memberikan efek jera kepada para pelaku dapat terwujud.

\section{DAFTAR PUSTAKA}

\section{A. Buku}

Fajar ND, Mukti dan Yulianto Achmad. Dualisme Penelitian Hukum Normatif dan Empiris. (Yogyakarta: Pustaka Pelajar, 2015).

Faisal Salam, Moch. Hukum Pidana Militer di Indonesia. (Bandung: Mandar Maju, 2006).

Hamzah, Andi. Asas-Asas Hukum Pidana. (Jakarta: PT Rineka Cipta, 2008).

Lamintang, P.A.F. Dasar-Dasar Hukum Pidana Indonesia. (Jakarta: Sinar Grafika, 2016).

Mahmud, Peter. Penelitian Hukum Edisi Revisi. (Jakarta: Kencana Prenada Media Group, 2005).

Makarao, Moh. Taufik et al. Tindak Pidana Narkotika. (Jakarta: Ghalia Indonesia, 2005).

Mulyadi, Lilik. Bunga Rampai Hukum Pidana (Perspektif, Teoretis, dan Praktik). (Bandung: Alumni, 2008).

Muladi dan Barda Nawawi Arief. Teori dan Kebijakan Pidana. (Bandung: Penerbit Alumni, 1992).

Nawawi Arief, Barda. Bunga Rampai Kebijakan hukum Pidana (Perkembangan Penyusunan Konsep KUHP Baru). (Jakarta: Kencana Prenadamedia Group, 2014). 
Prodjodikoro, Wirjono. Asas-Asas Hukum Pidana Di Indonesia. (Bandung: Refika Aditama, 2009).

Sunarso, Siswanto. Politik Hukum Dalam Undang-Undang Narkotika. (Jakarta: Rineka Cipta, 2012).

Soekanto, Soerjono. Pengantar Penelitian Hukum. (Jakarta: Universitas Indonesia (UIPress), 2010).

Soekanto, Soerjono, dan Sri Mamudji. Penelitian Hukum Normatif (Suatu Tinjauan Singkat). (Jakarta: RajaGrafindo Persada, 2014).

Zahroni. Pencegahan Penyalahgunaan NAPZA. (Jakarta: Grafindo Awanawan, 1980).

\section{B. Undang-Undang}

Indonesia, Undang-Undang Dasar Republik Indonesia Tahun 1945.

Indonesia, Undang-Undang Nomor 1 Tahun 1946 tentang Kitab UndangUndang Hukum Pidana.

Indonesia, Undang-Undang Nomor 34 Tahun 2004 tentang Tentara Nasional Indonesia (Lembaran Negara Republik Indonesia Tahun 2004 Nomor 127, Tambahan Lembaran Negara Republik Indonesia Nomor 4439).

Indonesia, Undang-Undang Nomor 35 Tahun 2009 tentang Narkotika (Lembaran Negara Republik Indonesia tahun 2009, Nomor 5062).

Indonesia, Undang-Undang Nomor 48 Tahun 2009 tentang Kekuasaan Kehakiman (Lembaran Negara Republik Indonesia tahun 2009, Nomor 157).

\section{Putusan Pengadilan}

Indonesia, Putusan Pengadilan Militer Nomor 108-K/PM.II-09/AD/IV/2015

\section{Wawancara}

Peneliti. Wawancara, dengan Bapak Budi Prasetyo, selaku Dosen Fakultas Hukum Universitas Tarumanagara, (Jakarta, 18 Oktober 2018).

Peneliti. Wawancara, dengan Bapak Salomon Balubun, selaku Konstitut Otmil II-07 Jakarta, (Jakarta, 2 November 2018). 
Peneliti. Wawancara, dengan Bapak Satiman, selaku Panitera Pengadilan Militer II-08 Jakarta, (Jakarta, 8 November 2018).

Peneliti. Wawancara, dengan Bapak Agus Pambudi, selaku Hakim Pengadilan Negeri Jakarta Barat, (Jakarta, 21 Desember 2018). 